\title{
Commanding Right And Forbidding Wrong: A Behavioral Investigation Using The Rowing Game
}

\author{
Hazik Mohamed \\ PhD in Islamic Finance \\ Putra Business School, Malaysia \\ Stellar Consulting Group, Singapore \\ Email: hazik@stellarcg.com
}

\begin{abstract}
There have been many empirical investigationinto property rights and rule of law in economic development, they do not demonstrate how deep religious understanding in human behavior for mutually beneficial decision-making. This paper attempts to address this concern so as to understand religious beliefs in constructive actions. This paper investigates the degree of compliance of individual behavior to the Islamic commandment of 'commanding right and forbidding wrong', through a behavioral approach, to understand the pervasiveness of Islamic morality in our modern societies, and how Muslims actually behave as opposed to what the Qur'an prescribes for them. The methodology of this researchevaluates the actions of experiment participants (divided into religious affiliations) through a Rowing Game that was intended to test for the rule of 'commanding right and forbidding wrong'. "The game is a prototype of a social contract where it illustrates how 'mutual undertakings' create a psychological tension between individual rationality, group benefit and straightforward compliance to Allah's commandment" (Mohamed et al, 2018). The complex nature of this command and prohibition results from the varied understanding of who is responsible (and adept enough) to enforce it, during which time is appropriate to do so and by what means. In this particular experiment, Muslims and non-Muslims appear to perform the same, with negative priming effects on the Muslims and positive priming effects for the nonMuslims.
\end{abstract}

Keywords: Behavioral rules, Compliance, Religious primes, Social network.

JEL Classifications: D71, D91, E71

\section{A. Introduction}

The phrase 'commanding right and forbidding wrong' (بالمعروفو النهيعنالمنكر لأمر ا) is repeated throughout the Qur'an and instances reported though the Sunnah. In one verse, Allah s.w.t. calls for unity among the believers, and addresses them: "Let there be one community (ummah) of you, calling to right, and commanding right and forbidding wrong; those will be the successful" (Qur'an 3:104). In another verse He declares: "You were the best community (ummah) ever brought forth to men, commanding right and forbidding wrong 
..." (Qur'an 3:110). And again: "And the believers, the men and the women, are friends one of the other; they command right and forbid wrong" (Qur'an 9:71) - a verse, incidentally, that is notable for its explicit mention of cooperation among everyone in connection with the duty. The Prophet told his followers that victory and conquest lie ahead; if they live to see them, they should fear God, command right and forbid wrong. These examples show that the phrase is unambiguously embedded in the articulation of the holy Qur'an and exemplification through the Sunnah.

Mirakhor and Askari (2010) noted that Adam Smith (in The Theory of Moral Sentiments) "concisely and clearly shares some of the foundations of Islam: belief in the One and Only Creator; belief in the accountability of the Day of Judgment; belief in the necessity of compliance with the rules prescribed by the Creator; and belief that justice is achieved with full compliance with rules". This emphasizes the importance of the Quranic commandment of 'commanding right and forbidding wrong' as the rule that encapsulates all other rules (Capstone rule). The premise of it can be interpreted as upholding and enforcement of the rule of Law, in this case God's law. Thus, any nation, Muslim or otherwise, that wishes to govern adequately has to primarily preserve law and order by enforcing its laws to protect all rights and serve all its citizens.

However, we observe in our daily lives some contradictions between what people profess to believe in against how people behave in real-life circumstances.There is also a discrepancy in what is religiously prescribed to them as rules of conduct against their own actions. In fact, people sometimes behave in real-life directly opposite to what is expected of them by society (Ariely, 2008) and religion. Ideally, people are expected to adhere to their religious beliefs which they strongly defend, and act in ways that are decreed by the religious texts. However, numerous studies in behavioral economics show that human actions can be influenced by other belief systems, and are also heavily biased by their mental frames, cultural norms and social surroundings. For Muslims, the recommended framework of prescribed conduct have been clearly outlined in order to achieve perfection in behavior (adab) and to attain maximum utility in this world and Hereafter.

In this paper, we wanted to investigate the degree of compliance of individual behavior to the Islamic commandment of 'commanding right and forbidding wrong', through a behavioral approach, to understand the pervasiveness of Islamic morality in our modern societies. While empirical studies have proven the significance of trust and ethics in economic development, they have yet to demonstrate any evidence of religious understanding for mutually beneficial decision-making in human behavior. This 
paper attempts to address this concern where we will band our sample groups by religious affiliations in order to differentiate the rootedness of this rule of behavior in belief systems, through a priming instrument to heighten identity saliency in the subjects. These experiments, based on popular game theory experiments, were carried out in Singapore and Malaysia.

\section{B. Theoretical Foundation}

\section{Differences in Understanding Right from Wrong (Good and Evil)}

Goodness is rooted in love, a love that is pure and unselfish; evil on the other hand grows out of our egocentricity. Thus honesty, decency, compassion, generosity, selfless loyalty, faith, trust, forgiveness, a courage that is truly selfforgetful and justice are all expressions of such a love. As such they are expressions of what is good. On the other side, malice, greed, unrestrained envy, lust, indifference to justice, the incapacity to feel remorse or gratitude, the inability to forgive others, vindictiveness, vengefulness are expressions of egocentricity and, as such, they are forms of evil. In them, one is indifferent to the feelings of others and, at an extreme, blind to their humanity, to the ultimate vulnerability they share with us.

Muslim and non-Muslims' conception of the responsibility to prevent evil (wrongdoing)vary in crucial areas and the differences are very real, and can have severe consequences. The analysis of "commanding right and forbidding wrong" then has to begin with this variation in understanding of this moral duty.

There are significant differences as how Muslims and non-Muslims view particular things in terms of right and wrong. As we already know, these dissimilarities are most apparent when it concernsalcohol, gambling, pork, interest (riba) and women. Regardless, Muslim norms are typicallyunderstood by non-Muslims so much so that even they recognize these as moral or health risks. Although mainstream non-Muslim culture do not support an absolute ban of alcohol (and similarly the abuse of intoxicating substances like controlled narcotics), they do not consent the dangers ofintoxication, drunken rage or the effects of people becoming drug addicts and alcoholics. While non-Muslims are flexible in comparison with traditional Islamic customs with regards to women's dressing and segregation, they are concerned about the less desirable corollaries of the uninhibited interactions allowed between the sexes (Cook, 2001), particularly among the youth. It is perhaps only in the case of striving to eradicate interest (riba) by Islamic scholars that differs greatly, although the Abrahamic religions (Judaism and Christianity) acknowledge the prohibition of usury. It would be hard to imagine the financial world operating without interest in any of its economic transactions. It has become so embedded in our financial 
activities, that even most Muslims participate in it despite its religious prohibition, except only until recently with re-emergence of Islamic Finance. Yet, the world together has learnt to accept the interest-based nature of the economy with its inability to price the market adequately causing mispricings to products that have an interest rate benchmark, while the Islamic economic no-interest model labors to contend for a more accurately-priced market where all opportunity costs of financial resources are captured adequately. The 500-year imprint of the conventional interest-based economic system leaves a systemic problem difficult to overcome, even among Muslims themselves, possibly due to its embeddedness in the shared social structure (Granovetter, 1985).

On a personal level, the complexity of carrying out the Capstone Rule command has to do with notion of public and private liberty. The response that is so often opposed in forbidding wrong is minding one's own business, and this demarcates the private from what is public.Telling someone to mind his own business, especially a stranger, was a typical response to unsolicited efforts to correct a wrong, even in the Islamic tradition. During his westward journey through North Africa, IbnTumart (d. 524H/1130AD) found the people of DashrQallal (near Fez in Morocco) engaged in making music in mixed company. He sent two of his followers to forbid this wrong, but the response they met with was: "This is how we do things." When the disciples insisted to the offenders that IbnTumart was commanding them right (ma'ruf), they received the retort: "We go by our kind of right, and you go by yours; go away!" The replies are curt, but they clearly assert the moral sovereignty of the local community and the implications of moral judgment on others. Digging deeper, however, what are the actual reasons behind such terse responses? Is it the moral outrage of someone confronting intrusion into what are properly his own affairs, or the scornful annoyance of the toughened wrongdoer who has no intention of mending his ways?

\section{The Capstone Rule - Commanding Right and Forbidding Wrong}

The "duty of commanding the right and forbidding wrong, incumbent on individuals as well as the whole community, is the most important means of enforcement of prescribed rules of the Qur'an and the Sunnah" (Mirakhor, 2009) - it can be interpreted as the concept of Rule of Law. Muslim scholars normally reiterate the Qur'anic references to 'commanding right and forbidding wrong' also as hisbahlike they are two sides of the same coin. This duty has evolved from its initial usage of enjoining belief in the unity of God (forbidding polytheism) and the denial of the messengers of God to the duty of citizenship and a responsibility of being a member of the Islamic community (أمة). 
During the Umayyad governorship of the future caliph Marwan ibn alHakam (r. 64-5H/684-5AD). Marwan, leading the congregation in his role of governor, commits two ceremonial indecorums: he brings out the pulpit (منبر) on a feast-day, and he begins with the sermon (خطبة) before the prayer (صلاة). Speaking out against these ritual infractions, a man reprimanded Marwan: "You've gone against the normative practice (Sunnah)! You've brought out the pulpit on a feast-day, when it used not to be; and you've started with the sermon before the prayer!" Hearing this reprimand, one of the Companions of the Prophet Abu Said al-Khudri (d. 74H/693AD) affirmed that the man had discharged his religiousobligation, by quoting the Prophet : "Whoever sees a wrong (المنكر), and is able to put it right with his hand (ضعهابشكلصحيحبيد), let him do so; if he cannot, then with his tongue (معلسانه); if he cannot, then in his heart (فيقلبه), and that is the bare minimum of faith."

In the scrutiny of the tradition, the Prophet speaks not of 'forbidding' wrong but of 'righting' it, using a verb (غير) whose primary sense is 'to change'. From this, the scholars derive the phrase 'righting wrong' (taghyır al-munkar). Despite the difference in phrasing, most scholars take it for granted that 'forbidding wrong' and 'righting wrong' mean the same thing.

So where do we draw the line and to what extent does this Rule encompass? Some divided "right" into "obligatory" and "commendable", but allowed no such division of "wrong"; others presented arguments for more balanced positions. And there was a fairly general restriction of the duty to include only prevention, reserving punishment to the state or enforcement authority. Regardless the interpretation, the command in the holy book is still to "enjoin good and forbid evil" no matter the circumstances but the complexities of applying and carrying out the command can be generally resolved when done with tact and respectfulness.

\section{Literature Review}

The "social dimension of humanity is the tendency among humans to associate and behave as members of groups. Our beliefs, desires and behaviors are affected by social preferences, our interconnectedness and the social contexts in which we live and make decisions" (Mohamed et al, 2018). Some researchers view this social aspect as humans being 'group-minded individuals' who see the world from both a connected group as well as an individual perspective (Tomasello, 2014). To others, humans"understand what is in the minds of others and often act as if our brains are networked with the brains of other people" (Christakis and Fowler, 2010). According to Larsen et al (2015), socialization is the milieu in which we shape our identity and traits. It is through family, friends 
and what they term as 'socialization agents' that we discover our comparative competence levels, ways to achieve essential aspirations. We develop our benchmarks for behavior through social interactions, and we inherit and integrate the values of our family and of our culture which forms our social identity.

Our social tendencies exhibit behaviors that are not totally selfish (pursuit of self-interest) and wealth-maximizing actors (maximizing economic utility), as many economic models and policies assume; rather, we appreciate shared values like reciprocity and fairness, and are willing to go out of our wayto attain shared goals (World Bank, 2015) through cooperation. We also have aninclination to obey shared understanding on accepted rules of behavior, even if they do not benefit us individually and collectively (Henrich et al, 2005). We are often unconsciously and imperceptibly shaped by the actions and choices of the people around us and whilst the impact weakens as it pervades through the network connections, the "geometric number of influence points grows" (Christakis and Fowler, 2010) as the influence spreads. It affects many segments of our life (including our beliefs, our careers, our health and how we generally feel)-some for better and some for worse.

With respect to the social network, some people are on the edge of networks, others at the very heart of them. As evident in social media platforms like Facebook, Instagram and Twitter, some people have many connections, while others tend to be more private and do not. For networks to spread and be effective they need to be connected to other networks.For this to happen, there are some critical connectors who have multiple circles of friends whobecome the information bridge to flow between networks. In addition, social networks with lots of interconnections with other networks are more adept to solve novel problems than those networks which are insular.

\section{The Role and Influenceof Social Norms}

Social norms are what defines and keepsa society intact and serve as informal governance mechanisms that wield anauthoritative sway on individual decision making and behavior. Humans are naturally inclined to adhere to those norms-young children are taught and quickly learn the 'social rules of the game'-following norms and uphold them by punishing norm-violators. "Imitating behaviors is one of the key ways humans learn strategies for interacting in the world" (Mohamed et al, 2018).

Social compliance has a powerful influence on behaviors and isfrequently not given its due. Grameen Bank saw that banks would refrain from extending credit to poor Bangladeshis because they had no asset to hold against to mitigate 
risks to the capital. But by lending to small communities, he unwittingly exploited the power of peer pressure which guaranteed the micro-loans were paid back in a timely manner. Another example is Wikipedia, which is an open repository information system that literally anyone can input and/or modify. It has no centralized control and like many self-organizing teams with no formal authority, able to bring together the most agreed-upon datathrough self-policing and collective verification.

Unfortunately, unproductive social norms may also be sustained because of the organizing role they play in a society, which can be utilized inefficiently like the propagation of myths and superstitions, which can be counterproductive. Being deeplyrooted in the social psyche, norms can arouse strong reactions in the communities in which they operate. In these ways, "social norms can have large effects on both collective welfare and individual agency" (Boudet et al., 2013). Other negative instances include social and legal norms around gender and the prevalent prejudice towardsfemales. Altering such norms that contribute to undesirable social outcomes is an obvious policy goal for any progressive society, butforeseeing how policy may interact with norms can be difficult and unpredictable at scale. In a recent field experiment, a public education course in Mali actually amplified the gender gap in public participation by increasing the significance of public activity, which amplified the implications for females who partook in public life (Gottlieb, 2014). The intervention increased understanding, but it worsened gender inequality.

As such we can see that the duty of 'commanding right and forbidding wrong' weaves the very fabric of the social contract that we have within our networks and between social networks. In upholding this duty, the members of society were found to be contributing to moral enforcement through active engagement and ethical values transmission, that determines socially-acceptable practices. Every progressive society requires private-order as well as public institutions to work in tandem, in order to create and sustain the very order of the laws and values that is shared among the different social networks and representative of the whole society.

\section{Research Methodology}

\section{Sampling Design}

The experimentswere run in two different cities-Singapore and Kuala Lumpur to get a better representation for the study. The sample sizes were 30 in Singapore and 40 in Malaysia which though not comprehensively large, still had a good coverage of variations in age, education, gender and income (see Appendix 1). We understand that some previous studieswere limited to 
undergraduate or graduate groups since they were easy to procure and did not cost much. Also, the Muslim communities in Singapore and Kuala Lumpur are predominantly Sunni and follow the Shafi'e school of thought which offered less variation when scrutinizing Muslims as a group.

\begin{tabular}{|c|c|c|c|}
\hline Game & Decision Rules & Payoffs & Total Size \\
\hline $\begin{array}{l}\text { Test for Capstone } \\
\text { Rule (Rowing } \\
\text { Game) }\end{array}$ & $\begin{array}{l}\text { Player } 1 \text { \& Player } \\
2 \text { decide how fast } \\
\text { they want to row }\end{array}$ & $\begin{array}{l}\text { If rowing effort } \\
\text { matches, a } \\
\text { matching premium } \\
\text { is paid } \\
\text { accordingly. }\end{array}$ & $\begin{array}{l}38 \text { Non-Muslims } \\
(22 \text { primed) } \\
32 \text { Muslim }(16 \\
\text { primed) }\end{array}$ \\
\hline
\end{tabular}

Table 1: Decision Rules, Payoffs and Sample size.

\section{Research Procedure}

The objective of this study is to evaluate the behavior of a sample group (of players illustrative of Muslims and non-Muslims) in a given scenario (Rowing Game) that will test the Capstone Rule of "commanding right and forbidding wrong". The same game will be played by the two groups for consistency, and the instructions for the game will be read usingneutral terminology to eliminate potential bias or any influence to the outcomes. At the end of the scenario, the outcomes are recorded for analysis. It is a simple one-off game, in which the players instantaneously and individually choose their actions, and they do so only once. In order to obtain neutrality and objectiveness in the outcomes, the sample groupsare not informed of what is being tested for in the game to reduce possibility of subjects gaming the system and affecting the analysis of the results. Also, to "statistically control for religious effects, we use a priming instrument used by Shariff and Norenzyan (2007) to segregate the Islamic-salient subjects from non-Islamic subjects via sentence-unscrambling task" (Mohamed et al, 2018).

\section{Priming Instrument}

In order to "statistically control for religious effects, we use a priming instrument used by Shariff and Norenzyan (2007) to segregate the Islamic-salient subjects within the Muslim group as well as the religious-salient subjects within the non-Muslim group via sentence-unscrambling task" (Mohamed et al, 2018). 
The advantage of using this priming instrument is in its subtlety, compared with blatant primes.Subtle primes are more reliablein nudging behavior to conform to norms (Wheeler and Petty, 2001), which supports our framework of selfcategorization by the participants. Basically,"priming a social category temporarily increases the strength of affiliation with that category. Stronger affiliation with a category causes behavior to shift towards that category's norms, so comparing primed and unprimed behavior allows us to infer something about what the category's norms are and how they affect steady-state behavior" (Mohamed et al, 2018).

\section{Rowing Game (Experiment for The Capstone Rule)}

The Rowing Game was “designed to test for the Qur'anic Capstone Rule which is 'to command right and forbid wrong'. It is derived from the original Stag Hunt dilemma presented by Jean-Jacque Rousseau in 'A Discourse on Inequality' (1755) to illustrate how 'mutual undertakings' create a tension between individual rationality and group benefit. The game is a prototype of a social contract where the hunters have the choice of hunting hare or hunting deer. The chances of getting a hare are independent of what others do. There is no chance of bagging a deer by oneself, but the chances of a successful deer hunt go up sharply with the number of hunters. A deer is deemed much more valuable than a hare" (Mohamed et al, 2018).

The Rowing Game is based on David Hume (1739) who described two individuals who must row a boat. According to him, so long as both of the individuals choose to row, they can successfully move the boat and get to where they want to go (mutual goals). However, if the rowing was done in tandem with synchronized effortsthen the boat would be able to move efficiently to its destination in a straight line.If one rower does not cooperate and refuses to row, then the other wastes his effort and they go round in circles, splashing away in furious activity but not getting anywhere.

In our experiments, the game is played with actual cash transactions to indicate effort of rowing - S\$10/RM20 for maximum rowing effort, S\$5/RM10 medium effort and S\$2/RM5 for minimal effort. Players are given cash prior to the game to be utilized as they saw fit. In actuality, the rowers have to match their efforts in order to get to their destination efficiently; any mismatch (i.e. mismatch in rowing effort) will result in the boat straying off its intended course. A matching bonus is paid out to both players if their premiums match, accordingly. The participants are allowed to discuss their intentions, and the outcomes are recorded and subsequently analyzed. 


\section{E. Data Analysis And Discussion}

For the Rowing Game, "both rowers needed to match their effort and speed (in tandem) in order to move in a straight line which is the shortest distance and will enable the rowers to reach their destination most efficiently. This illustrates the need for all parties involved to acknowledge mutual goals and decide to achieve them together by making choices that are aligned to achieving them. When one party does not match the same effort to strive for those goals, the outcome will result in veering away from those goals. In 'commanding right and forbidding wrong', we expect outcomes to match at the highest value amount of S\$/RM10" (Mohamed et al, 2018). Both rowers are required to match their efforts so that boat travels straight to the destination or goal for the best outcome for mutually-beneficial goals.

Theoretically, the Rational Choice Theory indicates that a person will act in such a wayto balance costs against benefits in order to reach an outcome that maximizes personal advantage. But recent behavioral research has shownthatin order to achieve maximum mutual benefit, people seem to behave differently due to differing factors. Historical results from the Stag Hunt games (original variant of our Rowing Game) games show that:

i. reasoning aptitude and risk-aversion has no statistically significant effecton any aspect of behavioral outcomes.

ii. avoiding loss are genuine considerations in decision making

iii. monetary pay-offs can affect behavior, although payoff levels do not affect strategic decisions (Skyrms, 2004; Feltovich, et al., 2008).

From Tables1 and 2, it can be noted that the sample distribution in Singapore is 18 Non-Muslims (11 primed) and 12 Muslims (seven primed), while in Malaysia, it was 20 Non-Muslims (11 primed) and 20 Muslims (nine primed); in total there were 38 Non-Muslims (22 primed) and 32 Muslims (16 primed). 


\begin{tabular}{|c|c|c|c|c|c|c|c|c|}
\hline \multirow{2}{*}{$\begin{array}{l}\text { CAPSTONE (ROWING GAME) } \\
\text { Effort }\end{array}$} & \multicolumn{4}{|c|}{ Singapore } & \multicolumn{4}{|c|}{ Malaysia } \\
\hline & $\$ 2$ & $\$ 5$ & $\$ 10$ & Total & RM5 & RM7 & RM10 & Total \\
\hline Muslim & 0 & 2 & 10 & 12 & 5 & 3 & 12 & 20 \\
\hline Primed & 0 & 2 & 5 & 7 & 2 & 2 & 5 & 9 \\
\hline Unprimed & 0 & 0 & 5 & 5 & 3 & 1 & 7 & 11 \\
\hline Did not Match & & & & 0 & & & & 3 \\
\hline Non-Muslim & 0 & 3 & 15 & 18 & 6 & 2 & 12 & 20 \\
\hline Primed & 0 & 2 & 9 & 11 & 2 & 2 & 7 & 11 \\
\hline Unprimed & 0 & 1 & 6 & 7 & 4 & 0 & 5 & 9 \\
\hline Did not Match & & & & 1 & & & & 1 \\
\hline \multicolumn{9}{|l|}{ Ratios (\%) } \\
\hline Muslim & $0 \%$ & $17 \%$ & $83 \%$ & $100 \%$ & $25 \%$ & $15 \%$ & $60 \%$ & $100 \%$ \\
\hline Primed & $0 \%$ & $29 \%$ & $71 \%$ & $58 \%$ & $22 \%$ & $22 \%$ & $56 \%$ & $45 \%$ \\
\hline Unprimed & $0 \%$ & $0 \%$ & $100 \%$ & $42 \%$ & $27 \%$ & $9 \%$ & $64 \%$ & $55 \%$ \\
\hline Did not Match & & & & $0 \%$ & & & & $15 \%$ \\
\hline Non-Muslim & $0 \%$ & $17 \%$ & $83 \%$ & $100 \%$ & $30 \%$ & $10 \%$ & $60 \%$ & $100 \%$ \\
\hline Primed & $0 \%$ & $18 \%$ & $82 \%$ & $61 \%$ & $18 \%$ & $18 \%$ & $64 \%$ & $55 \%$ \\
\hline Unprimed & $0 \%$ & $14 \%$ & $86 \%$ & $39 \%$ & $44 \%$ & $0 \%$ & $56 \%$ & $45 \%$ \\
\hline Did not Match & & & & $6 \%$ & & & & $5 \%$ \\
\hline
\end{tabular}

Table 2: Response Breakdown for Rowing Game

In order to adequately analyze the data observed, we approached them from two angles - from the religious beliefs grouping, i.e. Muslims versus nonMuslim, and from the priming effects within the religious grouping, i.e. primed Muslim versus unprimed Muslim and primed non-Muslim versus unprimed non-Muslim. 


\begin{tabular}{|c|c|c|c|c|}
\hline \multirow{2}{*}{$\begin{array}{l}\text { CAPSTONE (ROWING GAME) } \\
\text { Effort }\end{array}$} & \multicolumn{4}{|c|}{ Combined SG \& MY } \\
\hline & S\$2/RM5 & S\$5/RM7 & S\$10/RM10 & Total \\
\hline Muslim & 5 & 5 & 22 & 32 \\
\hline Primed & 2 & 4 & 10 & 16 \\
\hline Unprimed & 3 & 1 & 12 & 16 \\
\hline Did not Match & & & & 3 \\
\hline Non-Muslim & 6 & 5 & 27 & 38 \\
\hline Primed & 2 & 4 & 16 & 22 \\
\hline Unprimed & 4 & 1 & 11 & 16 \\
\hline Did not Match & & & & 2 \\
\hline \multicolumn{5}{|l|}{ Ratios (\%) } \\
\hline Muslim & $16 \%$ & $16 \%$ & $69 \%$ & $100 \%$ \\
\hline Primed & $13 \%$ & $25 \%$ & $63 \%$ & $50 \%$ \\
\hline Unprimed & $19 \%$ & $6 \%$ & $75 \%$ & $50 \%$ \\
\hline Did not Match & & & & $9 \%$ \\
\hline Non-Muslim & $16 \%$ & $13 \%$ & $71 \%$ & $100 \%$ \\
\hline Primed & $9 \%$ & $18 \%$ & $73 \%$ & $58 \%$ \\
\hline Unprimed & $25 \%$ & $6 \%$ & $69 \%$ & $42 \%$ \\
\hline Did not Match & & & & $5 \%$ \\
\hline Combined & 11 & 10 & 49 & 70 \\
\hline Primed & 4 & 8 & 26 & 38 \\
\hline Unprimed & 7 & 2 & 23 & 32 \\
\hline Did not Match & & & & 5 \\
\hline \multicolumn{5}{|l|}{ Ratios (\%) } \\
\hline Combined & $16 \%$ & $14 \%$ & $70 \%$ & $100 \%$ \\
\hline Primed & $11 \%$ & $21 \%$ & $68 \%$ & $54 \%$ \\
\hline Unprimed & $22 \%$ & $6 \%$ & $72 \%$ & $46 \%$ \\
\hline Did not Match & & & & $7 \%$ \\
\hline
\end{tabular}

Table 3: Breakdown of Responses for Rowing Game.

Combining both country data, $69 \%$ of Muslims compared to $71 \%$ of nonMuslims chose the maximum payout matching bonus. When we segregate the results by religious grouping, both Muslims and non-Muslims seem to be about equal in working towards mutually beneficial outcomes. These results seem to indicate that both Muslim and non-Muslim groups in both countries equally want to adhere to the Capstone Rule, and are willing to cooperatein pursuit of those goals (to maximize payoffs) together. However, looking only at the Muslim group, the "priming effects seems to be negative for them, both in SG (71\% primed versus $100 \%$ unprimed) and MY (56\% primed versus $64 \%$ unprimed)".

When the data from both countries were combined (see Table 3), the "negative priming effects still persist-Muslims 63\% primed versus 75\% unprimed as compared to non-Muslims 73\% primed and 69\% unprimed" 
(Mohamed et al, 2018). This seems to indicate that this group of primed Muslims would 'command right and forbid wrong' at a lower-to-moderate rate rather than at the expected highest level, indicated by S\$10/RM10. There can be several possible explanations to this observation. Firstly, it may be a slanted understanding of moderationin mutually-beneficial goals, especially when compared to the purely maximizing payoffs as understood in neo-classical economic theory. Secondly, it could also be interpreted that when viewed in terms of payoffs alone, primed Muslims were less economically-driven to maximize them than non-Muslims, since to them, economic benefit alone is not the goal.Instead, they may be swayed by non-economic factors like social and/or spiritual benefits or other intangible reasons, which were not evident (to them) in the game scenario. Thirdly, it could be related to the discussion in earlier section where there appears to be a conflict of interpretations to the extent of carrying out the Capstone Rule command, especially when the reprimand is confronted by outright rejection and dismissal.

While the duty of 'commanding right and forbidding wrong' is the Capstone Rule in Islam, our results do not show that priming had apositive effect on Muslims, unlike their non-Muslim counterparts. This is certainly not an expected outcome, particularly when the rules for 'commanding right and forbidding wrong' is deemed a Capstone Rule in Islam.Perhaps one explanation could be that the complexity of the nature of this command and prohibition results from the varied understanding of who is responsible (and adept enough) to enforce it, during which time is appropriate to do so and by what means. Another explanation could be that religious effects improves behavior towards mutually-beneficial outcomes, especially in maximizing payoffs, in non-Muslims more than in Muslims. This is also true from previous findings "that although payoff levels do not affect strategic decisions, monetary pay-offs can affect behavior". However, a critical analysis of Muslim behavior alone here suggests that this behavioral evidence points to the failure to uphold a significant (capstone) rule of behavior in real life, which may be able to explain some shortcomings of the Muslim community and their current state of affairs. Despite the noble and enlightened rules set by the religion, Muslim nations continue to underperform in key areas of governance and corporate stability due to the failure to speak out or act against non-Islamic behaviors such as corruption, repression and injustice. This results in mistrust and loss of faith in such non-compliant Muslim leaders and those Islamic organizations and corporations which do not carry out what is expected of them, morally and operationally as an institution. Effective leadership incorporates a set of core (moral) values which are translated throughout the organization, and 
these strengthen the organizational performance through enforcement of core values and rules of behaviors at all levels, beginning with the highest levels of leadership.

Table 4: Overall Performance for both Cities (Islamic and Priming Effects)

\begin{tabular}{|c|c|}
\hline SUMMARY & \\
\hline & $\begin{array}{l}\text { Capstone Rule - Commanding } \\
\text { Right and Forbidding Wrong }\end{array}$ \\
\hline $\begin{array}{l}\text { Muslim } \\
\quad \text { Priming Effects }\end{array}$ & $\mathrm{P}<\mathrm{UnP}$ \\
\hline $\begin{array}{l}\text { Non-Muslim } \\
\text { Priming Effects }\end{array}$ & $P>U n P$ \\
\hline $\begin{array}{l}\text { Combined (M \& nM) } \\
\text { Priming Effects }\end{array}$ & $P>$ Un $P$ \\
\hline Muslim vs non-Muslim & $M=$ non $M$ \\
\hline
\end{tabular}

where $\mathrm{P}=$ primed; $\mathrm{UnP}=$ unprimed subjects and $\mathrm{M}=$ Muslim and nonM = nonMuslim participants

and $>$ means performs better and $<$ means conversely according to the primary criteria of the experimental game

From Table 4, it can be observed that positive priming effects in nonMuslims appear to indicate that religious effects improve behavior towards mutually-beneficial outcomes, especially in maximizing payoffs. In terms of grouping, both Muslims and non-Muslims seem to be equally driven in working towards mutually beneficial outcomes.

With regards to interpreting our findings, we wish to advise prudence since this is a behavioral study which can be subjected to various interpretations. First, it is possible that priming the religious identity salience may have been too subtleto be obvious, but its effects should not be dismissed. It is possible that we did not have sufficient statistical power due to sample size (budget constraints) to detect the effect. It is also probable that the power of our religious identity salience priming varies by religiosity or groupsdepending on their spiritual or religious adherence through practice and their understanding of religious doctrines. Hence, our positive and negative findings deserve greater attention than if there were null findings. Further verification of these findings should be repeated in more countries, as we know that Muslims are not a homogenous 
group and there are multiple variations across tribes, races and cultures across the globe. In fact, we acknowledge that our results should not be taken as representative of all other Muslims in other countries. Instead, these experiments should be repeated in other countries, in order to have a more complete understanding of religious and priming effects.

\section{F. Conclusion}

From a social network perspective, we note from our literature review that people are influenced by their social circles like their friends, and also the extended network of their friends' friends, and even their friends. So, we can deduce that a community which works positively together with its social network and institutions - within the confines of the Shari'ah-will strengthen the understood moral values and thecommunity will enjoy prosperity, progress and stability. Conversely, if the basic unit(i.e. the citizen) of the community is disengaged of his/her moral responsibility of encouraging what is good and discouraging what is bad, the community will become the victim of ignorance (جهل), negativity (نلبية), confusion (انحراف), deading to collapse (الانهيار), disintegration (تفسخ) and corruption (فساد). Hence, the conditions for a multi-racial and multi-religious society where every citizen makes up the social structure, is that hisbah is exerted with respect for the sanctity (حرمة) of all citizens and their rights, Muslim and non-Muslim alike. Deep understanding of the (Shari'ah) Law, as well as vastexperience of realism (معرفةالواقع), and profoundknowledge of politics and governance (فهمالسياستو الحكم) are also essential to navigate the intricacies of governancein order to dispense justice so as to maintain a well-functioning social order within our present integrated social structure. Muslim countries would benefit from such compliance to Islamic traditions and acceptance of different beliefs and how they can be motivated to achieve collective success.

From a policy standpoint, the behavioral evidence and insights from this research show that the interaction of individual perception of duty and moral judgement is more multifaceted than is usuallydiagnosed or acknowledged. However, the prospect for immediateintercessions and corrections to amend established inaccurateperceptions is bigger than imagined. The significance of applying insightful findings from appliedbehavioral and psychology research to public perception of everyday events is gaining popularity-though moreso in advanced countries than in developing ones. In a broader sense, applications of Islamic tenets can be understood as utilitarian nudges to rejuvenate ineffectual legislative, political and economic institutions to enrich and expand corporate 
governance, socio-economic equality, justice and hence, performance outcomes across the community, inwardly as well as outwardly.

\section{References}

Abu Dawud al-Tayalisi (d. 204H/819AD), Musnad, Hyderabad, 1321.

Ahlerup, P., O. Olsson, and D. Yanagizawa (2007).Social Capital versus Institutions in the Growth Process.extended working paper version available at <http:/ / www.hgu.gu.se/item.aspx?id=2465>.

Ahmad, Makram Muhammad, Mu'amara am muraja'a: Hiwarqadat altatarruf fi sijn al-'aqrab, Cairo: Dar al-Shuruq, 2002.

Ariely, D. (2008). Predictably Irrational: The Hidden Forces that Shape our Decisions. London: HarperCollins.

Bayhaqi (d. 458H/1066AD), al-Sunan al-kubra, Hyderabad 1344-55.

Boudet, A. M. M., Petesch, P., Turk, C. with Thumala, A. (2013). On Norms

and Agency: Conversations about Gender Equality with Women and Men in 20 Countries. Directions in Development Series. Washington, DC: World Bank.

Bukhari (d. 256H/870AD), Sahih, ed. L. Krehl, Leiden 1862-1908.

Carl, N. and Billari F.C. (2014).Generalized Trust and Intelligence in the United States.PLoS ONE 9(3): e91786. doi:10.1371/journal.pone.0091786

Cook, M. (2001). Commanding Right and Forbidding Wrong in Islamic Thought. Cambridge University Press.

Christakis, N. and Fowler, J. (2010). Connected - The Amazing Power of Social Networks and How They Shape Our Lives. Harper Press, UK.

Einhorn, H. (1972). Expert Measurement and Mechanical Combination. Organizational Behavior and Human Performance, 7:86-106.

Feltovich, N., A. Iwasaki, and S.H. Oda (2008). Payoff Levels, Loss Avoidance, and Equilibrium Selection in the Stag Hunt: An Experimental Study, Working Paper, University of Aberdeen.

Gottlieb, J. (2014). Why Women Participate Less in Civic Activity: Evidence from Mali. Unpublished paper. http://mgape.files.wordpress.com/2013/06/gottlieb_civic-behaviour.pdf.

Granovetter, M. (1985). Economic Action and Social Structure: The Problem of Embeddedness. American Journal of Sociology 91 (3): 481-510.

Henrich, J, Boyd, R, Bowles, S, Camerer, C, Fehr, E, and Gintis, H. (2004). Foundations of Human Sociality: Economic Experiments and Ethnographic Evidence from Fifteen Small-Scale Societies. Oxford, U.K.: Oxford University Press. 
Hume, D. (1978). A Treatise of Human Nature (Second Edition). Clarendon Press, Oxford,.Edited by L. A. Selby-Bigge.Revised by P. Nidditch.First published 1739.

IbnTaymiyya (d. 728H/1328AD), al-Amrbil-ma'rufwal-nahy an al-munkar, ed. S. al Munajjid, Beirut 1984 (default edition); ed. M. R. Salim, Cairo, 1997.

IslamiArdakani, Hasan, Amr bah ma'rufwanahyazmunkar, Qumm 1375.

Khallal, Abu Bakr al- (d. 311H/923AD), al-Amrbil-ma'rufwal-nahy an almunkar, ed. A. A. Ata, Cairo 1975 (default edition).

Kharrazi, Muhsin al-, al-Amrbil-ma'rufwal-nahy an al-munkar, Qumm 1415.

Paula Bermann | Rechtte Utrecht | RechtteVoet | Rozenberg Publishers | Voices

Larsen, K. S., Ommundsen, R. and van der Veer, K. (2015).Being Human.Chapter 2. Cultural and Social Dimensions Of The Self. Rozenberg Series 1. EHV Academicpress $\mathrm{GmbH}$, Bremen.

Le Tourneau, R. (1969). The Almohad Movement in North Africa in the Twelfth and Thirteenth Centuries, Princeton.

Levy, R. (1957).The Social Structure of Islam, Cambridge.

Mirakhor, A. and Askari, H. (2010).Islam and the Path to Human and Economic Development, Palgrave Macmillan, New York.

Mirakhor, A. (2009), Islamic Economics and Finance: An Institutional Perspective, IIUM Journal of Economics and Management, 17(1), pp.31-72.

Mobarak, A. M., and Rosenzweig, M. (2013).Informal Risk Sharing, Index Insurance, and Risk Taking in Developing Countries. American Economic Review 103 (3): 375-80.

Mohamed, H., Mirakhor, A. and Erbaş, N. (2018), Belief and Rulecompliance : An Experimental Comparison of Economic Behaviors. Academic Press, Elsevier.

Nasa i (d. 303/915), Sunan, ed. H. M. al-Mas'udi, Cairo n.d.

Qiraati, Muhsin, Amr bah ma'rufwanahyazmunkar, Tehran 1375 sh.

Rifai, Talib al-, 'al-Amrbil-ma'rufwal-nahy an al-munkar', al-Najaf, 2 no. 2, (March 1968)

SalihiZayn al-Din al- (d. 856H/1452AD), al-Kanz al-akbarfil-amrbilma'rufwalnahy an al-munkar, Riyadh and Mecca 1997 (default edition).

Shariff, A. and Norenzayan, A. (2007). God Is Watching You: Priming God Concepts Increases Prosocial Behavior in an Anonymous Economic Game. Psychological Science 18: 803-809.

Skryms, B. (2001). The Stag Hunt. Presidential Address. Pacific Division of the American Philosophical Association, CA. 
Tomasello, M. (2014).A Natural History of Human Thinking. Cambridge, MA: Harvard University Press.

Wheeler, S. C., and Petty, R. E. (2001). The Effects of Stereotype Activation on Behavior: A Review of Possible Mechanisms. Psychological Bulletin 127(6), 797-826.

World Bank.(2015). World Development Report 2015.Mind, Society, and Behavior. Washington, DC: World Bank. 


\section{Appendix}

Appendix 1a: Sample Size and Ratios of Background Spread

\begin{tabular}{|c|c|c|c|c|}
\hline Sample Size & Singapore & Malaysia & Total & Ratio \\
\hline Sample Sub-total & 30 & 40 & 70 & $100 \%$ \\
\hline Muslim & 12 & 20 & 32 & $46 \%$ \\
\hline Non-Muslim & 18 & 20 & 38 & $54 \%$ \\
\hline Atheist & 1 & 0 & 1 & \\
\hline Buddhist & 6 & 10 & 16 & \\
\hline Catholic & 3 & 1 & 4 & \\
\hline Christian (non-Catholic) & 1 & 3 & 4 & \\
\hline Free-thinker & 5 & 3 & 8 & \\
\hline Hindu & 1 & 3 & 4 & \\
\hline Taoist & 1 & 0 & 1 & \\
\hline Age & 30 & 40 & 70 & $100 \%$ \\
\hline $20 \mathrm{~s}$ & 10 & 18 & 28 & $40 \%$ \\
\hline $30 \mathrm{~s}$ & 10 & 16 & 26 & $37 \%$ \\
\hline 40s & 9 & 6 & 15 & $21 \%$ \\
\hline $50 \mathrm{~s}$ & 1 & 0 & 1 & $1 \%$ \\
\hline Gender & 30 & 40 & 70 & $100 \%$ \\
\hline Male & 17 & 20 & 37 & $53 \%$ \\
\hline Female & 13 & 20 & 33 & $47 \%$ \\
\hline Education & 30 & 40 & 70 & $100 \%$ \\
\hline Tertiary & 19 & 38 & 57 & $81 \%$ \\
\hline Non-tertiary & 11 & 2 & 13 & $19 \%$ \\
\hline Income & 30 & 40 & 70 & $100 \%$ \\
\hline$<\mathrm{S} \$ / \mathrm{RM} 24 \mathrm{k}$ per annum & 6 & 14 & 20 & $29 \%$ \\
\hline S\$/RM24k to 36k per annum & 14 & 13 & 27 & $39 \%$ \\
\hline$S \$ / R M 36 k$ to $48 k$ per annum & 6 & 10 & 16 & $23 \%$ \\
\hline$>\mathrm{S} \$ / \mathrm{RM} 72 \mathrm{k}$ per annum & 4 & 3 & 7 & $10 \%$ \\
\hline
\end{tabular}


Appendix 1b: Size/Ratios of Muslim vs non-Muslim and Primed vs Unprimed Groupings

\begin{tabular}{llc|c|c}
\hline Sample Size & Singapore & Malaysia & Total \\
\hline Sample Sub-total & $\mathbf{3 0}$ & $\mathbf{4 0}$ & $\mathbf{7 0}$ \\
& Muslim & 12 & 20 & $\mathbf{3 2}$ \\
& Non-Muslim & 18 & 20 & $\mathbf{3 8}$ \\
Primed & & & & \\
& Muslim & $\mathbf{1 8}$ & $\mathbf{2 0}$ & $\mathbf{3 8}$ \\
& Non-Muslim & 7 & 9 & 16 \\
Unprimed & & 11 & 11 & 22 \\
& Muslim & $\mathbf{1 2}$ & $\mathbf{2 0}$ & $\mathbf{3 2}$ \\
& Non-Muslim & 5 & 11 & 16 \\
& & 7 & 9 & 16 \\
Ratios (\%) ) & & & \\
\hline Sample Sub-total & Singapore & Malaysia & Total \\
\cline { 2 - 5 } & Muslim & $\mathbf{1 0 0 \%}$ & $\mathbf{1 0 0 \%}$ & $\mathbf{1 0 0 \%}$ \\
& Non-Muslim & $40 \%$ & $50 \%$ & $46 \%$ \\
& & $60 \%$ & $50 \%$ & $54 \%$ \\
Primed & & & & \\
& Muslim & $\mathbf{6 0 \%}$ & $\mathbf{5 0 \%}$ & $\mathbf{5 4 \%}$ \\
& Non-Muslim & $37 \%$ & $28 \%$ & $31 \%$ \\
Unprimed & & $\mathbf{4 0 \%}$ & $\mathbf{5 0 \%}$ & $\mathbf{4 6 \%}$ \\
& Muslim & $17 \%$ & $28 \%$ & $23 \%$ \\
& Non-Muslim & $23 \%$ & $23 \%$ & $23 \%$ \\
\hline
\end{tabular}

